\title{
Pertumbuhan Artemia sp. dengan Pemberian Ransum Pakan Buatan Berbeda
}

\author{
Ali Djunaedi \\ Jurusan Ilmu Kelautan, Fakultas Perikanan dan Ilmu Kelautan, Universitas Diponegoro \\ JI. Prof. Soedarto, SH. Kampus UNDIP Tembalang, Semarang 50275 \\ E-mail : alidjunaedi@ymail.com
}

\begin{abstract}
Abstrak
Silase ikan sebagai pakan buatan Artemia sp mempunyai beberapa keunggulan diantaranya memiliki kandungan nutrisi yang tinggi dan kontinuitas ketersedian sebagai pakan dapat terpenuhi. Keunggulan yang dimiliki silase ikan ini sangat tepat diterapkan dalam menunjang pertumbuhan Artemia sp. Penelitian ini bertujuan untuk megetahui pengaruh berbagai dosis silase ikan terhadap pertumbuhan Artemia sp. Metode yang digunakan adalah eksperimental laboratories. Perlakuan yang diterapkan terdiri dari 4 perlakuan yaitu pemberian silase ikan A (10 mg/L), B (20 mg/L), C (30 mg/L) dan D (40 mg/L) dengan ulangan masing-masing 3 kali. Parameter ukur adalah Pertambahan berat mutlak, pertambahan panjang dan tingkat kelulushidupan. Hasil pengamatan menunjukkan bahwa rata-rata pertambahan berat mutlak dan pertumbuhan panjang tertinggi diperoleh perlakuan $D$ yaitu $7,99 \pm 0,05 \mathrm{mg}$ dan $8,8 \pm 0,25 \mathrm{~mm}$, terendah diperoleh perlakuan A yaitu $6,46 \pm 0,27 \mathrm{mg}$ dan $7,2 \pm 0,32 \mathrm{~mm}$ serta untuk tingkat kelulushidupan tertinggi diperoleh perlakuan D yaitu $31,09 \pm 1,29 \%$, terendah diperoleh perlakuan A yaitu 9,67 $\pm 2,96 \%$.
\end{abstract}

Kata Kunci : Artemia sp. Silase, Laju Pertumbuhan, Tingkat Kelulushidupan

\begin{abstract}
Silase is a liquid protein made from trash fish which is decomposed by enzims. Silase has some advantages ie, high nutrition value, easy to produce, economic value and could be produce easily. These could be aplied to support the growth of Artemia sp. The aim of this research is to investigate effect of the various dose of silase on the growth level of Artemia sp. These research was conducted at Laboratorium Pakan Alami Balai Besar Pengembangan Budidaya Air Payau(BBPAP), Jepara. Experimental laboratories was used with completely randomized design. The treatments were doses of silase: A $(10 \mathrm{mg} / \mathrm{L}) ; B(20 \mathrm{mg} / \mathrm{L}) ; C$ (30 $\mathrm{mg} / \mathrm{L})$ and $\mathrm{D}(40 \mathrm{mg} / \mathrm{L})$. The individual weight, length and survival rate were measured. The result showed that the highest average of individual absolute growth (weight) was reached on treatment $D(7,99+0,05 \mathrm{mg})$, while the lowest on treatment $A(6,46+0,27 \mathrm{mg})$. The highest length growth was reached on treatment $D(8,8+0,25 \mathrm{~mm})$, while the lowest on theatment $A$ $(7,2+0,32 \mathrm{~mm})$. The highest survival rate of Artemia sp was reached on treatment D $(31,09+$ $1,29 \%)$ and the lowest on treatment $A(9,67+2,96 \%)$.
\end{abstract}

Keywords : Artemia sp, Silase, Growth rate, Survival rate

\section{PENDAHULUAN}

Pengembangan usaha budidaya Artemia sp. merupakan alternatif yang tepat untuk dilakukan di tambak garam, mengingat harga kista Artemia sp. Sampai saat ini masih relatif tinggi (Mai Soni. 2004). Artemia sp. adalah jenis zooplankton yang merupakan makanan bermutu tinggi bagi berbagai jenis benih ikan, udang, serta kepiting. Artemia sp. mempunyai keunggulan apabila dibandingkan dengan jenis plankton lainnya, sebab Artemia sp. dapat disediakan dalam jumlah yang cukup, tepat waktu dan berkesinambungan (Sorgeloos, 2001) 
Keunggulan yang dimiliki Artemia sp. ini menjadikan biota ini banyak diminati dalam dunia usaha pembenihan untuk dijadikan sebagai pakan baik udang, ikan maupun kepiting dan lainnya. Seiring dengan berkembangnya usaha pembenihan maka permintaan Artemia sp. pun semakin meningkat dan untuk mengantisipasi permintaan yang semakin meningkat maka perlu adanya pengembangan budidaya Artemia sp.

Penelitian tentang pemberian pakan pada budidaya Artemia sp. telah dilakukan ,Tetraselmis chuii dan dedak digunakan sebagai ransum pakan pada pemeliharaan Artemia sp. (Sorgeloos, 2001). Hersapto et al., (1997) menggunakan dedak dan bungkil kelapa pada budidaya Artemia sp. Salah satu alternatif pemecahan masalah tersebut adalah substitusi bungkil kelapa dengan silase ikan (Mai soni, 2004).

Silase ikan juga mempunyai nilai nutrisi yang tinggi, baik itu protein $(47,58 \%)$ maupun lemak (18,56\%). Pembuatan silase ikan tidak membutuhkan biaya yang banyak, peralatan yang digunakan sederhana, dan tidak tergantung pada keadaan cuaca sehingga kontinuitas penyediaan silase ikan sebagai pakan Artemia sp. dapat terpenuhi. Selanjutnya dikatakan oleh Yunizal (1986) bahwa silase ikan harganya murah, pembuatanya mudah dilakukan, tahan lama, tidak terpengaruh cuaca serta mengurangi masalah pencemaran lingkungan hidup yang biasanya terjadi di berbagai tempat kegiatan perikanan.

Berdasarkan uraian tersebut maka peluang keberhasilan budidaya Artemia sp. dengan pemberian silase ikan sangat memungkinkan sehingga perlu dilakukan suatu penelitian tentang pemanfaatan berbagai dosis silase ikan sebagai pakan dalam usaha budidaya Artemia sp. untuk meningkatkan pertumbuhan yang optimal.

\section{MATERI DAN METODE}

Biota yang digunakan dalam penelitian ini adalah Artemia sp. yang di peroleh dari hasil penetasan kista, produksi tambak Desa Surodadi, Kecamatan Kedung, Kabupaten Jepara. Air media yang digunakan bersalinitas $80 \mathrm{ppt}$ diperoleh dari hasil pengenceran garam jenuh (200 ppt). Garam jenuh bersalinitas 200 ppt didapatkan dengan melarutkan garam krosok dengan air laut bersalinitas 31 ppt.

Pakan yang digunakan dalam pemeliharaan Artemia sp. adalah silase ikan. Silase ikan diperoleh dari hasil olahan ikan rucah yaitu ikan Munir (Upeneus mollucclensis) yang diperoleh dari Pendaratan dan Pelelangan ikan Ujung Batu Jepara. Wadah yang digunakan sebanyak 12 buah berupa ember plastik berbentuk conical dengan kapasitas air 25 liter, diisi air masing-masing 20 liter.

Metode yang digunakan dalam penelitian ini adalah metode eksperimen. Rancangan percobaan yang digunakan adalah rancangan acak lengkap (RAL) dengan empat perlakuan dan masingmasing perlakuan diulang sebanyak 3 kali. Empat perlakuan yang digunakan yaitu: Perlakuan A pemberian silase ikan dengan dosis $10 \mathrm{mg} / \mathrm{L}$; Perlakuan B pemberian silase ikan dengan dosis $20 \mathrm{mg} / \mathrm{L}$; Perlakuan C pemberian silase ikan dengan dosis 30 $\mathrm{mg} / \mathrm{L}$ dan Perlakuan $\mathrm{D}$ pemberian silase ikan dengan dosis $40 \mathrm{mg} / \mathrm{L}$

Data yang dukumpulkan dalam pelaksanaan penelitian ini meliputi data pertambahan berat mutlak dan pertambahan panjang serta tingkat kelulushidupan Artemia sp. Data dianalisis menggunakan uji One way ANOVA yang dapat dilanjutkan dengan Post hoc test uji LSD (least signifikan difference)

\section{HASIL DAN PEMBAHASAN}

\section{Pertambahan berat mutlak individu Artemia} sp.

Hasil pengamatan pertambahan berat mutlak individu Artemia sp. sebagai respon perlakuan yang dicobakan selama penelitian tersaji pada Gambar 1. Histogram diatas menunjukkan bahwa dari keempat perlakuan tersebut, perlakuan D 
memberikan pertambahan berat mutlak individu yang tertinggi $(7,99+0,05 \mathrm{mg})$ dan terendah pada perlakuan A $(6,46+0,27$ $\mathrm{mg}$ ).

\section{Pertambahan panjang Artemia sp.}

Hasil pengamatan pertambahan panjang Artemia sp. sebagai respon perlakuan yang dicobakan selama penelitian tersaji pada Gambar 2.

Gambar 2 menunjukkan bahwa ratarata pertambahan panjang Artemia sp. selama penelitian, tertinggi dicapai pada perlakuan $D(8,8 \pm 0,25 \mathrm{~mm})$, terendah diperoleh perlakuan $A(7,2 \pm 0,32 \mathrm{~mm})$.

\section{Tingkat kelulushidupan Artemia sp.}

Hasil pengamatan tingkat kelulushidupan Artemia sp. terhadap perlakuan yang dicobakan selama penelitian disajikan pada Gambar3.

Gambar 3 diatas menunjukkan bahwa rata-rata tingkat kelulushidupan Artemia sp. terbaik ditunjukkan pada perlakuan D $(31,09 \pm 1,29 \%)$, terendah diperoleh perlakuan A $(9,67 \pm 2,96 \%)$.

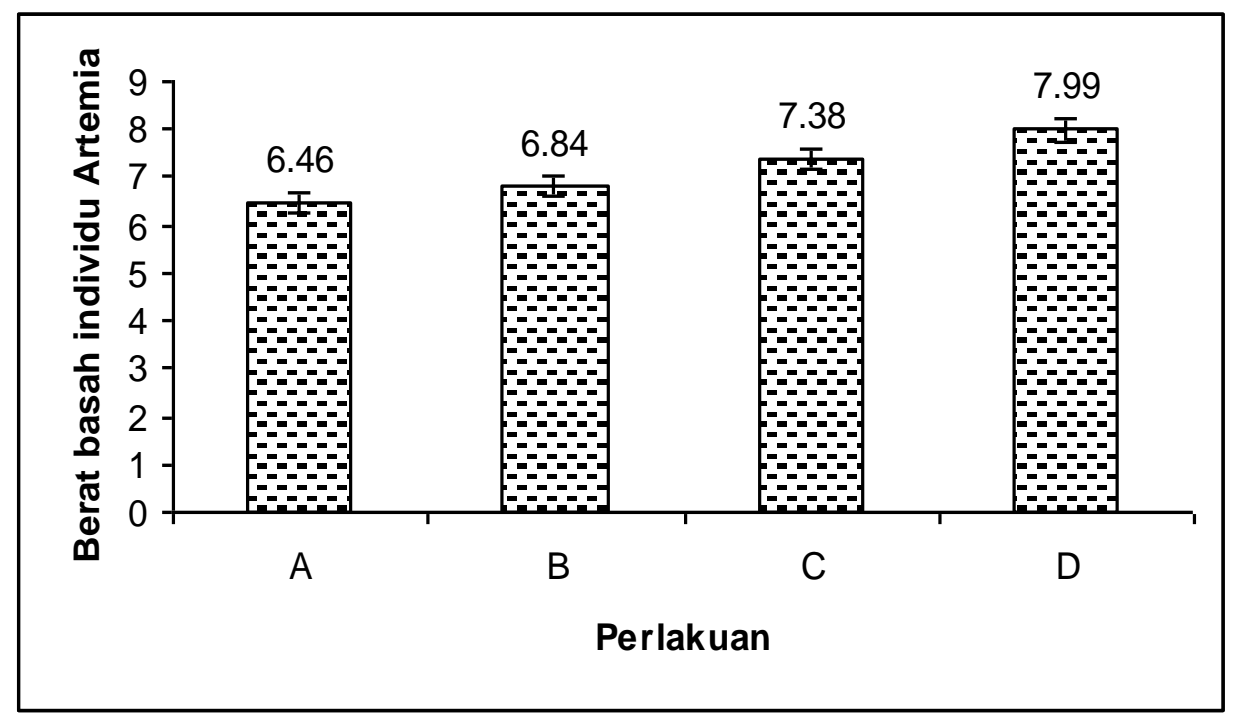

Gambar 1. Histogram rata-rata pertambahan berat mutlak individu (mg) Artemia sp.

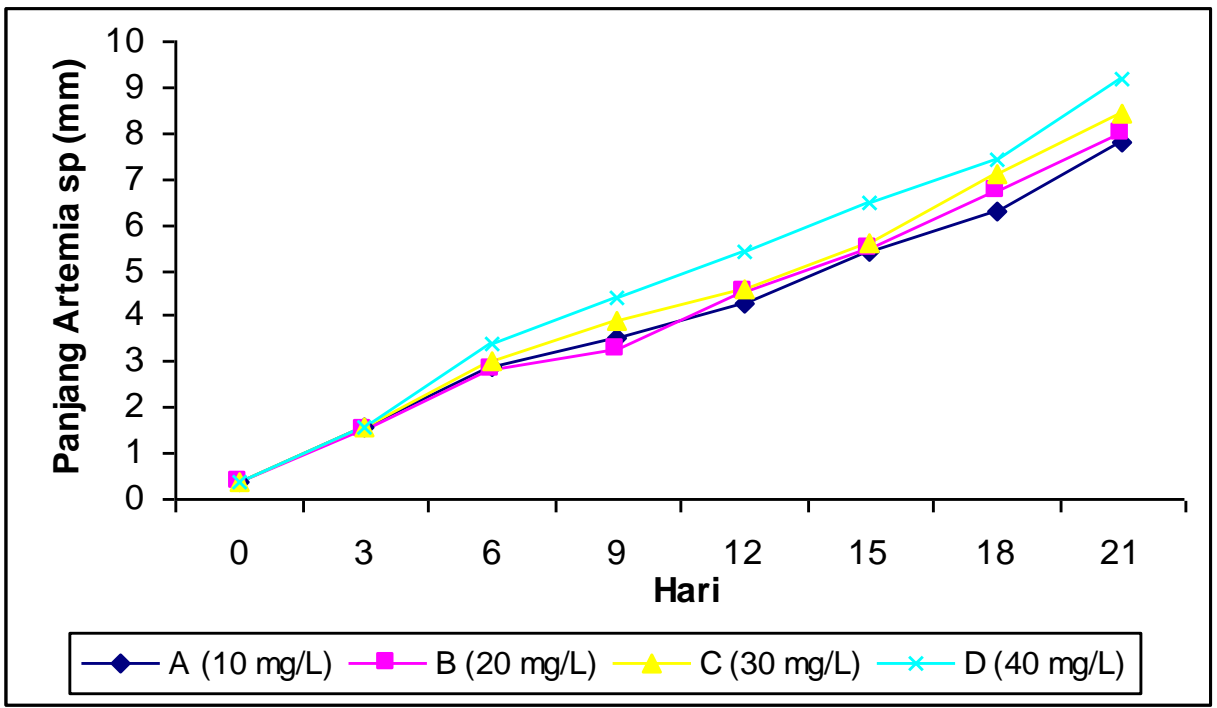

Gambar 2. Grafik rata-rata panjang (mm) Artemia sp. selama penelitian. 


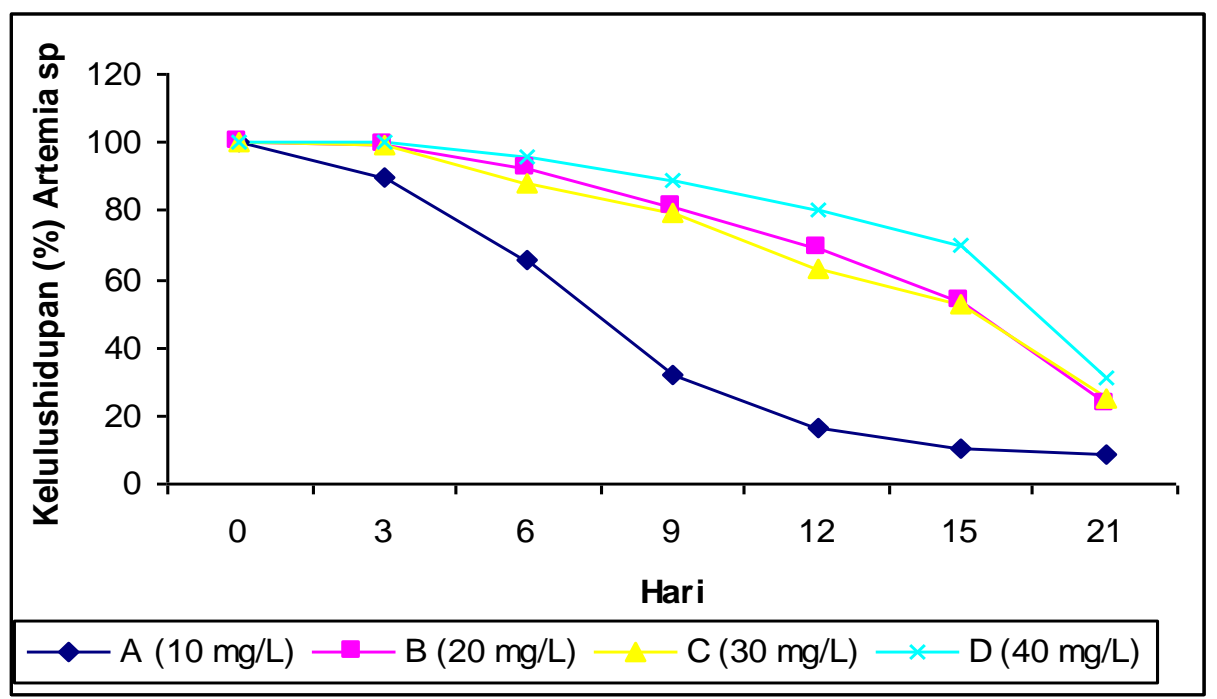

Gambar 3. Grafik tingkat kelulushidupan Artemia sp. selama penelitian

Berdasarkan hasil penelitian pemberian pakan silase ikan pada Artemia sp. menunjukkan bahwa pertumbuhan berat maupun panjang meningkat dengan bertambahnya dosis silase ikan. Hasil analisis menunjukkan bahwa perlakuan dosis silase ikan memberikan pengaruh sangat nyata $(p>0,01)$ terhadap pertumbuhan berat dan panjang Artemia $\mathrm{sp}$. Hal tersebut diduga pemberian Silase ikan dengan kandungan protein sebesar 47,58 \% merupakan nutrisi yang cukup untuk pertumbuhan Artemia sp. Koefisien pertumbuhan Artemia sp. berkorelasi positif dengan banyaknya kandungan protein dalam sumber pakan (Johnson, 1980 dalam Susanto et al., 1999). Disamping itu silase ikan yang memiliki energi sebesar 5,199 kkal/g dapat mencukupi kebutuhan untuk proses metabolisme Artemia sp. sehingga dapat memacu pertumbuhan Artemia sp. dengan baik.

Tingkat pertumbuhan berat dan panjang yang berbeda-beda diantara perlakuan diakibatkan oleh kandungan protein dalam pakan, dimana semakin besar protein (sampai batas tertentu) yang terkandung dalam pakan maka tingkat pertumbuhannya semakin tinggi. Hal tersebut sesuai dengan Suryanti et al., (2004) yang menyatakan bahwa kandungan protein yang tinggi dapat memacu pertumbuhan. Hal ini didukung oleh Ahmad et al., (1992) menyatakan bahwa protein merupakan komponen terbesar dalam pakan karena sebagian besar akan digunakan sebagai sumber energi. Pada perlakuan yang diberi pakan silase ikan dengan dosis yang meningkat, menunjukkan tingkat pertumbuhan yang semakin tinggi hal ini disebabkan oleh dosis silase ikan yang semakin besar maka kandungan nutrisinya juga semakin tinggi sehingga input energi dari protein menjadi lebih besar yang mengakibatkan tingkat pertumbuhannya semakin besar.

Seperti pernyataan Effendie (2002), bahwa pertumbuhan akan terjadi apabila terdapat kelebihan input asam amino (protein) berasal dari makanan. Bahan yang berasal dari makanan akan digunakan oleh tubuh untuk metabolisme dasar, pergerakan, produksi organ seksual, perawatan bagian-bagian tubuh untuk menganti sel-sel yang sudah tidak terpakai. Bahan-bahan yang tidak berguna akan dikeluarkan oleh tubuh. Apabila terdapat bahan berlebihan dari keperluan tersebut diatas akan dibuat sel baru sebagai penambahan unit atau pengganti sel dari bagian tubuh.

Hasil analisis juga menunjukkan bahwa perlakuan yang diterapkan yaitu pemberian silase ikan pada Artemia sp. berpengaruh sangat nyata ( $p>0,01$ ) terhadap tingkat kelulushidupan Artemia sp. Perlakuan D memberikan nilai kelulushidupan Artemia sp. yang tertinggi $(31,09 \%)$. Hal ini diduga bahwa dosis 
pakan yang diberikan mempengaruhi tingkat kelulushidupan Artemia sp. dalam hal ini, dosis yang lebih tinggi memberikan tingkat kelulushidupan yang tinggi pula. Biasanya, organisme kelompok crustacea yang sedang mengalami penggantian kulit berada dalam keadaan lemah sehingga dapat menyebabkan kematian. Oleh karena itu, faktor makanan memegang peranan penting pada saat mengalami moulting.

Selama mengalami moulting kebutuhan protein untuk pertumbuhan tercukupi sehingga peningkatan pertumbuhan mencapai optimal, sedangkan kandungan lemak dalam silase ikan dapat memenuhi kebutuhan energi yang digunakan selama pergantian kulit. Hal ini sesuai dengan pernyataan Vos dan Rosa (1980), bahwa faktor makanan dan kondisi media sangat menentukan tingkat sintasan Artemia sp. yang dibudidayakan. Selain itu diperkuat juga oleh Sorgeloos et al., (2001) menyatakan bahwa kelangsungan hidup dan pertumbuhan Artemia sp. sangat tergantung dari kualitas dan kuantitas pakan yang tersedia.

Terjadinya penurunan nilai kelulushidupan Artemia sp. pada perlakuan dengan dosis yang rendah ini sangat erat kaitanya dengan pakan yang dikomsumsi oleh Artemia sp., dimana tingkat kelulushidupan mengalami penurunan pada dosis pakan yang lebih rendah. Hal ini disebabkan pemberian dosis pakan yang rendah menyebabkan terjadinya kompetisi dalam mendapatkan makanan, sehingga Artemia sp. yang mampu memperoleh makanan ditengah-tengah terjadinya persaingan maka dapat mempertahankan hidupnya sebaliknya Artemia sp. yang kalah dalam kompetisi ini akan berakibat buruk terhadap kelangsungan hidupnya.

Selain itu diduga perbedaan tingkat kelulushidupan Artemia sp. pada semua perlakuan disebabkan persaingan untuk mendapatkan ruang gerak antar Artemia sp. dalam media pemeliharaan, hal ini dapat dilihat bahwa tingkat kelulushidupan Artemia sp. dari keempat perlakuan yang dicobakan hanya mampu menghasilkan kelulushidupan yang tertinggi (31,09 \%).
Hasil pengamatan dan penghitungan jumlah populasi yang dilakukan tiap 3 hari sekali disini terlihat jelas bahwa terjadi persaingan dalam memperoleh ruang gerak Artemia sp. yang dapat mempertahankan kehidupannya akan tumbuh dengan baik, sedangkan Artemia sp. yang tidak mampu bersaing dalam ruang gerak yang sempit akan tersisihkan hingga mengalami kematian. Hasil pengamatan juga menunjukkan semakin meningkat pertumbuhan Artemia sp. tingkat kelulushidupannya semakin menurun.

\section{KESIMPULAN}

Hasil penelitian ini dapat diambil kesimpulan bahwa pemberian pakan silase ikan berpengaruh sangat nyata $(p>0,01$ ) terhadap pertumbuhan Artemia sp. Dosis silase ikan $40 \mathrm{mg} / \mathrm{L}$ (perlakuan D) memberikan pertambahan berat mutlak (7,99 mg), panjang individu $(8,8 \mathrm{~mm})$ dan tingkat kelulushidupan $(31,09 \%)$ tertinggi dibanding perlakuan lainnya.

\section{DAFTAR PUSTAKA}

Ahmad, T. M., Ardiansyah. dan Usmunandar, D. 1992. Pengaruh pemberian pakan berkadar Protein berbeda terhadap pertumbuhan kerapu Lumpur. Jurnal Penelitian Perikanan Indonesia. 8 (2) : 71 - 80.

Hersapto, Yunus. dan I. Setyadi. 1997. Penelitian pemanfaatan Bungkil Kelapa dalam budidaya Artemia salina di tambak. Jurnal Penelitian Perikanan Indonesia. 3 (1) : 29 - 35.

Mai Soni, A.F., 2004. Budidaya Artemia terpadu di tambak garam. desa Surodadi, Kecamatan Kedung, Kabupaten Jepara, Laporan Tahunan 2004. Balai Besar Budidaya Air Payau Jepara (in press).

Sorgeloos, P., Dhert,P., Candrevan P., 2001. The use the brine shrimp Artemia in marine fish larviculture. Aquaculture 200, 147-159.

Suryanti, Y., A. Priyadi, dan H. Mundriyanto. 2004. Pengaruh rasio energi dan protein yang berbeda terhadap efisiensi pemanfaatan protein pada 
benih baung (Mystus nemurus C.V.). Penelitian Perikanan Indonesia. 9 (1) : $31-36$.

Susanto, B., Sugama, Aslianti, T., dan Wahyuadi, K. 1999. Pemanfaatan tambak garam di daerah pesisir untuk produksi kista Artemia sp. Warta. Penelitian Perikanan Indonesia. 5 (3) : $10-14$.

Tacon, A.G.J., 1987. The Nutrition and Feeding of Farmer Fish and Shirmp. A Training Manual II. Nutrien Source and Composition. FAO of the United Nation Brazilia. Brasil. $173 \mathrm{hlm}$.

Vos, J. dan Rosa, D.L. 1980. Manual on Artemia production in salt ponds in the Philippines.FAO/UNDP-BFAR, Brackishwater Aquaculture Demonstration and Training Project, $\mathrm{PHI} / 75 / 005.45 \mathrm{pp}$.

Yunizal. 1986. Teknologi Pengawetan Ikan dengan Proses Silase. INFIS. Jakarta. $49 \mathrm{hlm}$. 